\title{
Effect of Continuous Irrigation on Soil Texture, Bulk Density and Saturated Hydraulic Conductivity of Some Soils in Hirakud Command Area of Odisha, India
}

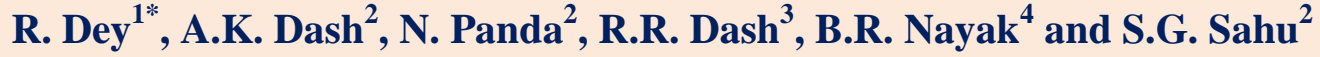 \\ ${ }^{1}$ Department of Agricultural Chemistry \& Soil Science, Faculty of Agriculture, Bidhan \\ Chandra Krishi Viswavidyalaya, Mohanpur-741252, Nadia, West Bengal, India \\ ${ }^{2}$ Department of Soil Science \& Agricultural Chemistry, College of Agriculture, Orissa \\ University of Agriculture and Technology, Bhubaneswar-751003, Odisha, India \\ ${ }^{3}$ Department of Agronomy, College of Agriculture, Orissa University of Agriculture and \\ Technology, Bhubaneswar-751003, Odisha, India \\ ${ }^{4}$ Regional Research \& Technology Transfer Station (RRTTS), Chiplima, Sambalpur-768025, \\ Odisha, India \\ *Corresponding author
}

\section{A B S T R A C T}

\begin{tabular}{|l|}
\hline Ke y w o r d s \\
GPS, Bulk density, \\
Textural class, \\
Saturated hydraulic \\
conductivity
\end{tabular}

Present study was undertaken at Hirakud command area of Odisha to investigate the effect of continuous irrigation on soil texture, bulk density and saturated hydraulic conductivity of different soils. Soil samples were collected from 15 spots each at irrigated areas and unirrigated areas in two different depths at $0-15 \mathrm{~cm}$ and $15-30 \mathrm{~cm}$ with Global Positioning System (GPS). Both loose and core samples from each spots were collected and analysed for different physical properties. The textural classes for surface soil of both the areas varied from sandy loam to sandy whereas for sub surface soil the textural classes of both irrigated as well as unirrigated areas varied from sandy clay loam to sandy and sandy loam to sandy clay loam respectively. Sand content was more in irrigated areas $(91.4 \%)$ than unirrigated areas $(83 \%)$ due to continuous irrigation. The range of bulk density for unirrigated areas varied highest from $1.51-1.87 \mathrm{Mg} / \mathrm{m}^{3}$ than irrigated areas. The value of saturated hydraulic conductivity for surface soil was higher than sub surface soil of both irrigated and unirrigated areas. The sand content of surface soil of both areas was positively correlated with bulk density and saturated hydraulic conductivity.

\section{Introduction}

Assured irrigation is one of the key factors for successful as well as sustainable crop production. In Odisha, Hirakud dam is a multipurpose project built across the Mahanadi river about $14 \mathrm{~km}$ upstream of
Sambalpur town. The command area of Hirakud dam covers 5 blocks of Sambalpur, 6 blocks of Bargarh, 2 blocks of Sonepur and 1 block of Bolangir district of Odisha. Due to indiscriminate application of irrigation water with inadequate drainage facilities water logging is a major problem. Due to continuous 
water availability rice-rice is the major cropping system in Hirakud command area. Indiscriminate and continuous use of irrigation water creates the problem of rise in ground water, formation of hard pan at plough sole layer, drainage congestion and low water use efficiency. Continuous irrigation also affects the physical properties of the soil which indirectly affects the soil health. Taha and Nanda (2003) reported that in both irrigated and unirrigated condition surface soil is light textured. Sand content was more in irrigated soil sample than that of unirrigated soil. The bulk density of sub surface layer of irrigated areas was higher than that of unirrigated areas due to compaction developed by continuous rice-rice cropping system. The hydraulic conductivity for surface soil was higher than sub surface soil of both irrigated and unirrigated areas. The information regarding the effect of continuous use of water on physical properties of soil under Hirakud command area is not sufficient. Therefore, the present study was conducted to generate some information regarding the effect of soil texture on bulk density and hydraulic conductivity of different soils under continuous irrigation in Hirakud command area.

\section{Materials and Methods}

\section{Soil sampling and Laboratory analysis}

Hirakud command area consists of mainly four districts of Odisha such as Bargarh, Sambalpur, Bolangir and Sonepur. Soil samples were collected from some blocks of above four districts. Loose soil samples as well as core samples from two different depth i.e. 0-15 cm (surface) and $15-30 \mathrm{~cm}$ (sub surface) were collected from 15 spots each from irrigated and unirrigated areas. The longitude and latitude of each sampling spot was recorded through Global positioning system. These samples were labelled properly and brought to laboratory for analysis of different properties by different standard methods.

The sand, silt and clay content along with textural class of soil samples were determined by hydrometer method (Piper, 1950), bulk density of the soil was determined by the core method (Black, 1965) and saturated hydraulic conductivity $(\mathrm{K})$ was determined in the laboratory by using constant head method (Israelson and Hansel, 1962).

\section{Results and Discussion}

The sand percentage in both the soil depths of irrigated areas was varied from 58.0-91.4\% (Table 1). In case of surface sample $(0-15 \mathrm{~cm})$ sand content varied from 64.0-91.4\% with a mean value of $79.4 \%$ whereas the values varied from 58.0-88.6\% in case of sub surface sample $(15-30 \mathrm{~cm})$ with a mean value of 75.6 $\%$ (Table 1). On the other hand the sand percentage in both the soil depths of unirrigated areas varied from 52-83 \% (Table $2)$. In case of surface sample $(0-15 \mathrm{~cm})$ sand content varied from 54-83\% with a mean value of $72.45 \%$ whereas the values varied from $52-77 \%$ in case of sub surface sample $(15-30 \mathrm{~cm})$ with a mean value of $67.01 \%$ (Table 2). The mean sand content of surface soil $(0-15 \mathrm{~cm})$ of both irrigated as well as unirrigated areas was higher than that of sub surface layer which might be due to eluviation of clay particle from surface to sub surface layer. The result corroborated with the finding of Taha and Nanda (2003) regarding the sand content observed with soil profile study at Hirakud command areas of Odisha.

Silt content considering both the layers of irrigated areas varied from 1.4-19.4\% (Table 1). Both highest $(19.4 \%)$ and lowest $(1.4 \%)$ values were observed in sub surface soil. In surface soil, silt content varies from 2.6-16.6 $\%$ with mean value of $9.9 \%$ whereas that value varied from 1.4-19.4 \% with a mean 
value of $9.8 \%$ in sub surface soil (Table 1). Silt content considering both the layers of unirrigated areas varied from 4.6-21.4\% (Table 2). In surface soil, silt content varied from 4.6-21.4 \% with mean value of $12.72 \%$ whereas that value varied from 4.6-21.4\% with a mean value of $13.19 \%$ in sub surface soil (Table 2). There was no definite relationship observed with respect to the silt content of both surface and sub-surface layer of irrigated and unirrigated areas.

Irrespective of soil depth, the clay content of irrigated areas varied from 4.0-22.6\% (Table $1)$. The clay content of the surface soil varied from 4.0-20.6\% with a mean value of $10.8 \%$ whereas that value varied from 7.6-22.6\% with a mean value of $15.3 \%$ in sub surface soil (Table 1). The clay content of surface soil in irrigated area was less than that of subsurface soil indicating the removal of clay from surface and deposition of clay particle in the sub surface layer.

The clay content of unirrigated areas varied from 5.6-33.2\% (Table 2). The clay content of the surface soil varied from 5.6-26.6\% with a mean value of $14.83 \%$ whereas those values for sub surface soil varied from 9.6-33.2\% with a mean value of $19.8 \%$ (Table 2).

Table.1 The effect of continuous irrigation on textural class of irrigated soil samples

\begin{tabular}{|c|c|c|c|c|c|c|c|c|}
\hline \multirow[t]{2}{*}{ Sl. No } & \multicolumn{2}{|c|}{$\begin{array}{c}\text { Sand Content } \\
(\%)\end{array}$} & \multicolumn{2}{|c|}{$\begin{array}{c}\text { Silt Content } \\
(\%)\end{array}$} & \multicolumn{2}{|c|}{$\begin{array}{c}\text { Clay Content } \\
(\%)\end{array}$} & \multicolumn{2}{|c|}{ Textural classes } \\
\hline & Surface & $\begin{array}{c}\text { Sub } \\
\text { surface }\end{array}$ & Surface & $\begin{array}{c}\text { Sub } \\
\text { surface }\end{array}$ & Surface & $\begin{array}{c}\text { Sub } \\
\text { surface }\end{array}$ & Surface & $\begin{array}{c}\text { Sub } \\
\text { surface }\end{array}$ \\
\hline 1 & 73 & 71.0 & 12.6 & 10.6 & 14.4 & 18.4 & Sandy Loam & Sandy Loam \\
\hline 2 & 78 & 75.0 & 10 & 10.6 & 12 & 14.4 & Sandy Loam & Sandy Loam \\
\hline 3 & 64 & 58.0 & 15.4 & 19.4 & 20.6 & 22.6 & $\begin{array}{l}\text { Sandy Clay } \\
\text { Loam }\end{array}$ & $\begin{array}{c}\text { Sandy Clay } \\
\text { Loam }\end{array}$ \\
\hline 4 & 81.8 & 77.8 & 12.6 & 14.6 & 5.6 & 7.6 & Sandy & Sandy Loam \\
\hline 5 & 91.4 & 88.6 & 4.6 & 13.0 & 4 & 8.4 & Sandy & Sandy \\
\hline 6 & 75.8 & 67.8 & 10.6 & 12.6 & 13.6 & 19.6 & Sandy Loam & Sandy Loam \\
\hline 7 & 79.4 & 76.4 & 12 & 13.0 & 8.6 & 10.6 & Sandy Loam & Sandy Loam \\
\hline 8 & 82.6 & 80.6 & 9.4 & 1.4 & 8 & 18.0 & Sandy & Sandy \\
\hline 9 & 82.6 & 78.6 & 11.4 & 13.4 & 6 & 8.0 & Sandy & Sandy Loam \\
\hline 10 & 78.6 & 74.6 & 12.4 & 14.0 & 9 & 11.4 & Sandy Loam & Sandy Loam \\
\hline 11 & 82.6 & 80.6 & 3.4 & 1.4 & 14 & 18.0 & Sandy & Sandy \\
\hline 12 & 87.4 & 80.6 & 2.6 & 5.0 & 10 & 14.4 & Sandy & Sandy \\
\hline 13 & 79 & 75.0 & 16.6 & 4.6 & 4.4 & 20.4 & Sandy Loam & $\begin{array}{c}\text { Sandy Clay } \\
\text { Loam }\end{array}$ \\
\hline 14 & 74 & 71.0 & 9.4 & 10.4 & 16.6 & 18.6 & Sandy Loam & Sandy Loam \\
\hline 15 & 80 & 78.0 & 5.4 & 3.4 & 14.6 & 18.6 & Sandy & Sandy Loam \\
\hline Range & $\begin{array}{c}64- \\
91.4\end{array}$ & $\begin{array}{l}58.0- \\
88.6\end{array}$ & $\begin{array}{l}2.6- \\
16.6\end{array}$ & $\begin{array}{l}1.4- \\
19.4\end{array}$ & $4-20.6$ & $\begin{array}{l}7.6- \\
22.6\end{array}$ & & \\
\hline Mean & 79.4 & 75.6 & 9.9 & 9.8 & 10.8 & 15.3 & & \\
\hline
\end{tabular}


Table.2 The effect of continuous irrigation on textural class of unirrigated soil samples

\begin{tabular}{|c|c|c|c|c|c|c|c|c|}
\hline \multirow[t]{2}{*}{ Sl. No } & \multicolumn{2}{|c|}{$\begin{array}{c}\text { Sand Content } \\
(\%)\end{array}$} & \multicolumn{2}{|c|}{ Silt Content (\%) } & \multicolumn{2}{|c|}{$\begin{array}{c}\text { Clay Content } \\
(\%)\end{array}$} & \multicolumn{2}{|c|}{ Textural classes } \\
\hline & Surface & $\begin{array}{c}\text { Sub } \\
\text { surface }\end{array}$ & Surface & $\begin{array}{c}\text { Sub } \\
\text { surface }\end{array}$ & Surface & $\begin{array}{c}\text { Sub } \\
\text { Surface }\end{array}$ & Surface & $\begin{array}{c}\text { Sub } \\
\text { surface }\end{array}$ \\
\hline 1 & 72 & 70 & 14.4 & 13.6 & 13.6 & 16.4 & $\begin{array}{l}\text { Sandy } \\
\text { Loam }\end{array}$ & $\begin{array}{l}\text { Sandy } \\
\text { Loam }\end{array}$ \\
\hline 2 & 68 & 62 & 13.4 & 15.4 & 18.6 & 22.6 & $\begin{array}{l}\text { Sandy } \\
\text { Loam }\end{array}$ & $\begin{array}{c}\text { Sandy } \\
\text { Clay Loam }\end{array}$ \\
\hline 3 & 54 & 52 & 19.4 & 14.8 & 26.6 & 33.2 & $\begin{array}{l}\text { Sandy } \\
\text { Clay } \\
\text { Loam }\end{array}$ & $\begin{array}{c}\text { Sandy } \\
\text { Clay Loam }\end{array}$ \\
\hline 4 & 63.4 & 53.4 & 16.6 & 14.6 & 20 & 32 & $\begin{array}{c}\text { Sandy } \\
\text { Clay } \\
\text { Loam }\end{array}$ & $\begin{array}{c}\text { Sandy } \\
\text { Clay Loam }\end{array}$ \\
\hline 5 & 77.8 & 73.8 & 16.6 & 16.6 & 5.6 & 9.6 & $\begin{array}{l}\text { Sandy } \\
\text { Loam }\end{array}$ & $\begin{array}{l}\text { Sandy } \\
\text { Loam }\end{array}$ \\
\hline 6 & 58 & 54 & 21.4 & 21.4 & 20.6 & 24.6 & $\begin{array}{c}\text { Sandy } \\
\text { Clay } \\
\text { Loam }\end{array}$ & $\begin{array}{c}\text { Sandy } \\
\text { Clay Loam }\end{array}$ \\
\hline 7 & 79.8 & 73.8 & 10.6 & 14.6 & 9.6 & 11.6 & $\begin{array}{l}\text { Sandy } \\
\text { Loam }\end{array}$ & $\begin{array}{l}\text { Sandy } \\
\text { Loam }\end{array}$ \\
\hline 8 & 81.4 & 71.4 & 4.6 & 8.6 & 14 & 20 & Sandy & $\begin{array}{c}\text { Sandy } \\
\text { Clay Loam }\end{array}$ \\
\hline 9 & 72.6 & 68.6 & 19.4 & 19.4 & 8 & 12 & $\begin{array}{l}\text { Sandy } \\
\text { Loam }\end{array}$ & $\begin{array}{l}\text { Sandy } \\
\text { Loam }\end{array}$ \\
\hline 10 & 73.4 & 69 & 10.6 & 12.4 & 16 & 18.6 & $\begin{array}{l}\text { Sandy } \\
\text { Loam }\end{array}$ & $\begin{array}{l}\text { Sandy } \\
\text { Loam }\end{array}$ \\
\hline 11 & 81.4 & 74.4 & 4.6 & 7.6 & 14 & 18 & Sandy & $\begin{array}{l}\text { Sandy } \\
\text { Loam }\end{array}$ \\
\hline 12 & 83 & 75.4 & 10.6 & 4.6 & 6.4 & 20 & Sandy & $\begin{array}{c}\text { Sandy } \\
\text { Clay Loam }\end{array}$ \\
\hline 13 & 70 & 65.4 & 9.4 & 12 & 20.6 & 22.6 & $\begin{array}{c}\text { Sandy } \\
\text { Clay } \\
\text { Loam }\end{array}$ & $\begin{array}{c}\text { Sandy } \\
\text { Clay Loam }\end{array}$ \\
\hline 14 & 71 & 65 & 8.6 & 11.6 & 20.4 & 23.4 & $\begin{array}{l}\text { Sandy } \\
\text { Clay } \\
\text { Loam }\end{array}$ & $\begin{array}{c}\text { Sandy } \\
\text { Clay Loam }\end{array}$ \\
\hline 15 & 81 & 77 & 10.6 & 10.6 & 8.4 & 12.4 & Sandy & $\begin{array}{l}\text { Sandy } \\
\text { Loam }\end{array}$ \\
\hline Range & $54-83$ & $52-77$ & $4.6-21.4$ & $4.6-21.4$ & $5.6-26.6$ & $9.6-33.2$ & & \\
\hline Mean & 72.45 & 67.01 & 12.72 & 13.19 & 14.83 & 19.8 & & \\
\hline
\end{tabular}


Table.3 The effect of continuous irrigation on Bulk density $\left(\mathrm{Mg} / \mathrm{m}^{3}\right)$ of surface and sub-surface soils with respect to the both irrigated and unirrigated areas

\begin{tabular}{|c|c|c|c|c|}
\hline SI. No & \multicolumn{2}{|c|}{ Irrigated area } & \multicolumn{2}{c|}{ Unirrigated area } \\
\hline 1 & Surface & Sub surface & Surface & Sub surface \\
\hline 2 & 1.66 & 1.78 & 1.72 & 1.73 \\
\hline 3 & 1.6 & 1.73 & 1.67 & 1.77 \\
\hline 4 & 1.63 & 1.69 & 1.58 & 1.75 \\
\hline 5 & 1.79 & 1.81 & 1.65 & 1.70 \\
\hline 6 & 1.77 & 1.86 & 1.74 & 1.79 \\
\hline 7 & 1.72 & 1.79 & 1.58 & 1.65 \\
\hline 8 & 1.65 & 1.71 & 1.72 & 1.65 \\
\hline 9 & 1.62 & 1.75 & 1.73 & 1.67 \\
\hline 10 & 1.55 & 1.68 & 1.63 & 1.79 \\
\hline 11 & 1.67 & 1.72 & 1.71 & 1.80 \\
\hline 12 & 1.57 & 1.62 & 1.63 & 1.81 \\
\hline 13 & 1.62 & 1.76 & 1.78 & 1.82 \\
\hline 14 & 1.51 & 1.65 & 1.70 & 1.69 \\
\hline 15 & 1.59 & 1.64 & 1.60 & 1.51 \\
\hline Range & $1.51-1.79$ & $1.62-1.86$ & $1.58-1.78$ & $1.51-1.87$ \\
\hline Mean & 1.64 & 1.73 & 1.57 & 1.73 \\
\hline
\end{tabular}

Table.4 The effect of continuous irrigation on Hydraulic conductivity $(\mathrm{cm} / \mathrm{h})$ of surface and subsurface soils with respect to the both irrigated and unirrigated areas

\begin{tabular}{|c|c|c|c|c|}
\hline Sl. No & \multicolumn{2}{|c|}{ Irrigated area } & \multicolumn{2}{c|}{ Unirrigated area } \\
\hline & Surface & Sub surface & Surface & Sub surface \\
\hline 1 & 16.7 & 14.1 & 15.9 & 15.2 \\
\hline 2 & 18.6 & 17.8 & 16.8 & 14.0 \\
\hline 3 & 17.2 & 16.4 & 24.8 & 19.0 \\
\hline 4 & 11.8 & 10.8 & 17.2 & 15.8 \\
\hline 5 & 12.1 & 10.2 & 14.4 & 13.4 \\
\hline 6 & 14.2 & 11.8 & 22.4 & 17.4 \\
\hline 7 & 16.8 & 15.3 & 17.1 & 16.8 \\
\hline 8 & 17.3 & 15.8 & 16.3 & 15.3 \\
\hline 9 & 20.6 & 19.9 & 18.2 & 14.1 \\
\hline 10 & 16.5 & 15.8 & 16.2 & 13.6 \\
\hline 11 & 20.4 & 19.8 & 22.1 & 13.5 \\
\hline 12 & 17.5 & 16.5 & 12.4 & 13.0 \\
\hline 13 & 22.5 & 17.8 & 16.2 & 15.9 \\
\hline 14 & 19.4 & 18.9 & 22.4 & 17.5 \\
\hline 15 & 16.8 & 15.4 & 18.1 & $10.9-17.5$ \\
\hline Range & $12.1-22.5$ & $10.2-19.9$ & $12.4-24.8$ & 15.03 \\
\hline Mean & 17.2 & 15.7 & 18.0 & \\
\hline
\end{tabular}


Table.5 Correlation coefficient (r) of sandy soil texture and other parameters of surface soils of irrigated and unirrigated areas

\begin{tabular}{|c|c|c|c|}
\hline SI. No. & Area & Soil parameter & Correlation coefficient (r) \\
\hline 1 & Irrigated & Sand \% $-\mathrm{BD}\left(\mathrm{Mg} / \mathrm{m}^{3}\right)$ & 0.19 \\
\hline 2 & Unirrigated & Sand \% $-\mathrm{BD}\left(\mathrm{Mg} / \mathrm{m}^{3}\right)$ & 0.75 \\
\hline 3 & Irrigated & Sand \% $-\mathrm{HC}(\mathrm{cm} / \mathrm{h})$ & 0.74 \\
\hline 4 & Unirrigated & Sand \% $-\mathrm{HC}(\mathrm{cm} / \mathrm{h})$ & 0.89 \\
\hline
\end{tabular}
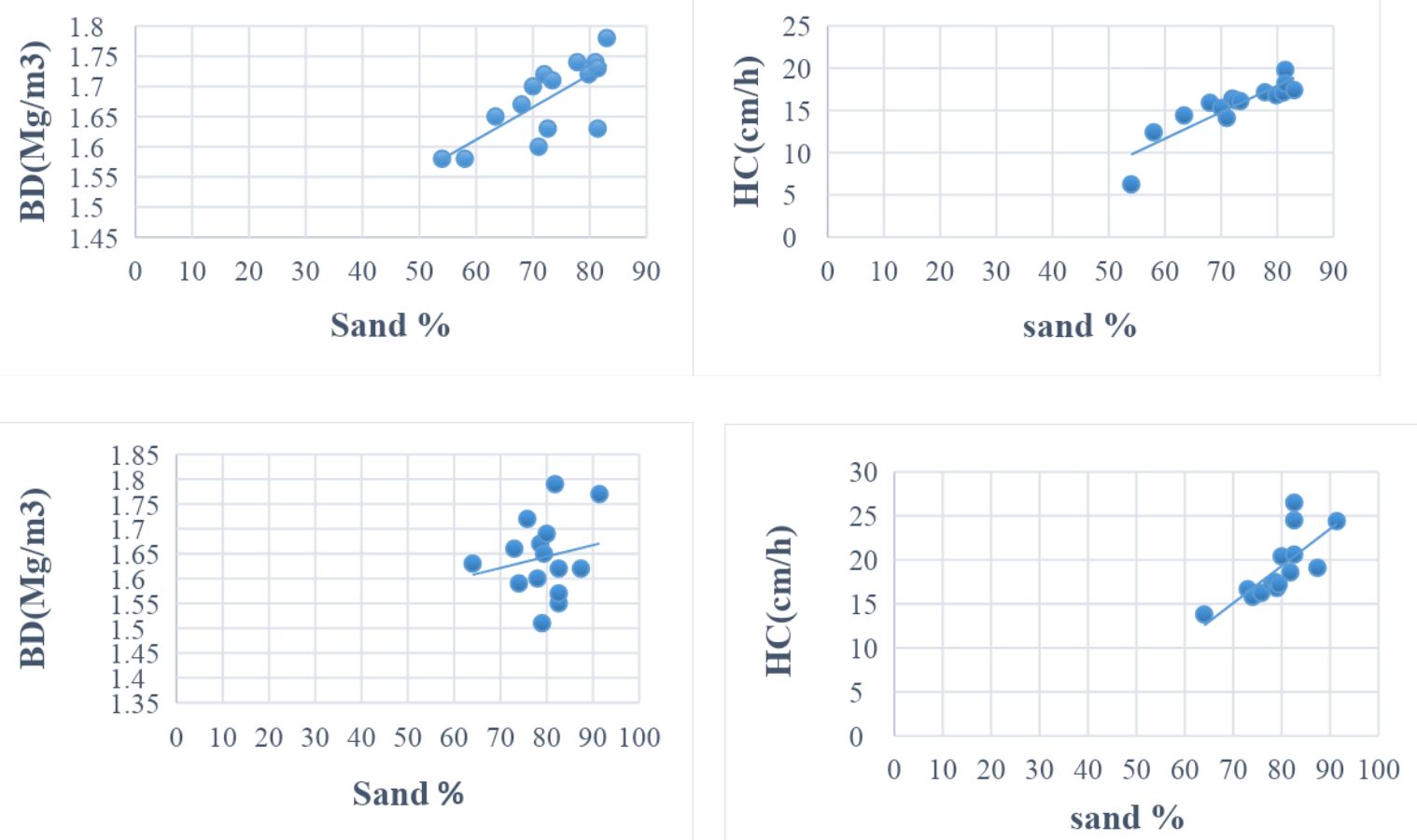

The clay content of surface soil in both irrigated and unirrigated areas were less than that of subsurface soil indicating the removal of clay from surface and deposition of clay particle in the sub surface layer.

The textural classes for surface soil varied from sandy loam to sandy whereas for sub surface soil these classes varied from sandy clay loam to sandy considering both the layers of soil sample of irrigated areas (Table 1). On the other hand in unirrigated areas the textural class of the surface soil varied from sandy to sandy loam whereas for subsurface area textured classes varied from sandy loam to sand clay loam (Table 2). The textural classes

for surface soil of both the areas varied from sandy loam to sandy whereas for sub surface soil the textural classes of both irrigated as well as unirrigated areas varied from sandy clay loam to sandy and sandy loam to sandy clay loam respectively.

\section{Effect of continues irrigation on bulk density of soils}

The bulk density of both surface and subsurface soils of irrigated areas of Hirakud command indicated that the bulk density values of surface soil ranged from 1.51-1.79 $\mathrm{Mg} / \mathrm{m}^{3}$ with a mean value of $1.64 \mathrm{Mg} / \mathrm{m}^{3}$, whereas for subsurface soil those values 
ranged from $1.62-1.86 \mathrm{Mg} / \mathrm{m}^{3}$ with a mean value of $1.73 \mathrm{Mg} / \mathrm{m}^{3}$ (Table 3). Similarly the $\mathrm{BD}$ of surface soil of unirrigated area varied from $1.58-1.78 \mathrm{Mg} / \mathrm{m}^{3}$ with a mean value of $1.57 \mathrm{Mg} / \mathrm{m}^{3}$ areas for subsurface soils or those values varied from 1.51 to $1.87 \mathrm{Mg} / \mathrm{m}^{3}$ with a mean value of $1.73 \mathrm{Mg} / \mathrm{m}^{3}$. The result indicated that the bulk density of surface layer of both irrigated and unirrigated areas was lower than that of sub surface soil. This is due to addition of more organic matter in surface layer through external sources along with crop residues incorporation and more manipulation of surface layer due to continuous crop growth.

This result was in agreement with the findings of Saikumar and Rao (2016) and Halder et al., (2015). Use of implements for cultivation of crop provide favourable situation for reduction in bulk density and more aeration. On the other hand, less amount of organic matter addition, more compaction due to use of implements and less disturbances increased the BD in subsurface layer. The mean BD of surface soils of irrigated area was higher (1.64 $\left.\mathrm{Mg} / \mathrm{m}^{3}\right)$ than that of unirrigated area (1.57 $\left.\mathrm{Mg} / \mathrm{m}^{3}\right)$. This might be due to more sand content along with continuing water supply which corroborates the result of Taha and Nanda (2003). The mean bulk density value of subsurface soils of both irrigated and unirrigated soils was similar which indicated that irrigation has no affected on the BD of lower layer.

\section{Effect of continues irrigation on saturated hydraulic conductivity of soil}

The saturated hydraulic conductivity values for surface soil samples of irrigated areas varied from $12.1-22.5 \mathrm{~cm} / \mathrm{h}$ with a mean value of $17.2 \mathrm{~cm} / \mathrm{h}$, whereas for subsurface soil those values ranged from $10.2-19.9 \mathrm{~cm} / \mathrm{h}$ with a mean value of $15.7 \mathrm{~cm} / \mathrm{h}$ (Table 4). Similarly the saturated hydraulic conductivity of surface soil of unirrigated area varied from
$12.4-24.8 \mathrm{~cm} / \mathrm{h}$ with a mean value of 18.0 $\mathrm{cm} / \mathrm{h}$ areas for subsurface soils whereas those values varied from $10.9-17.5 \mathrm{~cm} / \mathrm{h}$ with a mean value of $15.03 \mathrm{~cm} / \mathrm{h}$. The result revealed that the saturated hydraulic conductivity of surface soil of both irrigated and unirrigated areas was higher than that of sub surface soils. This is due to the addition of more organic matter through different cropping system in surface layer, improvement of soil porosity along with the manipulation of surface soil with different tillage implements.

On the other hand the organic matter content was less in the sub surface layer and more compaction in the subsurface layer which facilitates the reduction in hydraulic conductivity. This result corroborated with the result of Saikumar and Rao (2016). The mean saturated hydraulic conductivity of surface soils of irrigated area was lower (17.2 $\mathrm{cm} / \mathrm{h}$ ) than that of unirrigated area (18.0 $\mathrm{cm} / \mathrm{h}$ ). This might be due to more sand content, and higher BD with higher compaction which corroborates the result of Dec et al., (2008). On the other hand the mean saturated hydraulic conductivity value for subsurface soils of irrigated areas was higher $(15.7 \mathrm{~cm} / \mathrm{h})$ than that of unirrigated areas.

\section{Correlation study}

Sand content had a profound effect on soil bulk density and hydraulic conductivity. The simple correlation coefficient ( $r$ ) between sand and soil bulk density as well as sand and hydraulic conductivity for irrigated and unirrigated soil samples were studied (Table 5). Sand content was positively correlated with bulk density for irrigated areas as well as with unirrigated areas (Fig. 1 and 3). Similarly positive correlation was observed between sand content and hydraulic conductivity (Fig. 2 and 4) of irrigated areas and unirrigated areas. 
From this study it was concluded that irrespective of irrigated and unirrigated areas, sand content was more in surface soil than that of sub surface soil. Sand content was more in irrigated areas than unirrigated areas due to continuous irrigation. Irrespective of irrigated and unirrigated areas, clay content was more in sub surface soil than that of surface soil. Irrigated soil samples contained less amount of clay than unirrigated samples due to continuous irrigation. Saturated Hydraulic conductivity was higher in irrigated areas which were helpful for crop production. Sand content of surface soil of irrigated and unirrigated areas showed a positive correlation with soil bulk density and saturated hydraulic conductivity.

\section{References}

Black, CA. (1965). Methods of Soil Analysis, Part I and 2. American Society of Agronomy, Madison, Wisconsin, U.S.A.

Dec D, Dorner J, Becker- Fazekas O and Horn R. (2008). Effect of bulk density on hydraulic properties of homogenized and structured soils, Journal of soil science and plant nutrition, 8(1): 1-13.

Halder A, De S.K. and Tarafdar P.K. (2015). Hydraulic conductivity and its relationship with other properties of soil in cultivated land, Journal Crop and Weed, 11(1): 157-160.

Israelsen, O. W. and V.E. Hansen. (1962). Irrigation principles and practices. 3rd ed. John Willey and Sins, Inc. 447 p.

Piper, C.S., (1950). Soil and Plant Analysis. The University of Adelaide, Adelaide. pp 190-4.

Saikumar R and Rao C.N. (2016). Physical properties of chilli growing soils of Khammam district, An Asian Journal of Soil Science, 11(2): 324-331.

Taha M and Nanda SSK. (2003). Transformation of soil characteristics under continuous irrigation in ricebased farming system - A case study of Hirakud Command of Orissa, Agropedology, 13: 30-38.

\section{How to cite this article:}

Dey, R., A.K. Dash, N. Panda, R.R. Dash, B.R. Nayak and Sahu, S.G. 2019. Effect of Continuous Irrigation on Soil Texture, Bulk Density and Saturated Hydraulic Conductivity of Some Soils in Hirakud Command Area of Odisha, India. Int.J.Curr.Microbiol.App.Sci. 8(08): 836-843. doi: https://doi.org/10.20546/ijcmas.2019.808.096 